University of Nebraska - Lincoln

DigitalCommons@University of Nebraska - Lincoln

Agronomy \& Horticulture -- Faculty Publications

Agronomy and Horticulture Department

1969

Physiological Responses to Nitrogen in Plants

Yoshio Murata

National Institute of Agricultural Sciences, Konosu, Saitana, Japan

Follow this and additional works at: https://digitalcommons.unl.edu/agronomyfacpub

Part of the Plant Sciences Commons

Murata, Yoshio, "Physiological Responses to Nitrogen in Plants" (1969). Agronomy \& Horticulture -Faculty Publications. 197.

https://digitalcommons.unl.edu/agronomyfacpub/197

This Article is brought to you for free and open access by the Agronomy and Horticulture Department at DigitalCommons@University of Nebraska - Lincoln. It has been accepted for inclusion in Agronomy \& Horticulture -Faculty Publications by an authorized administrator of DigitalCommons@University of Nebraska - Lincoln. 
Published in Physiological Aspects of Crop Yield: Proceedings of a symposium sponsored by the University of Nebraska, the American Society of Agronomy, and the Crop Science Society of America, and held at the University of Nebraska, Lincoln, Nebr., January 20-24, 1969. Edited by Jerry D. Eastin, F. A. Haskins, C. Y. Sullivan, C. H. M. Van Bavel, and Richard C. Dinauer (Madison, Wisconsin: American Society of Agronomy \& Crop Science Society of America, 1969). Copyright (C) 1969 American Society of Agronomy \& Crop Science Society of America. Used by permission. 


\title{
Physiological Responses to Nitrogen in Plants
}

\author{
YOSHIO MURATA \\ National Institute of Agricultural Sciences \\ Konosu, Saitana, Japan
}

\section{INTRODUCTION}

Recent advances in crop physiology have given us some clues for analysis of the complex relationships of environmental factors, cultural conditions and genetic factors to crop yield. However, in order to accomplish this analysis, it is quite necessary to have concrete knowledge about the causal relationships and the time sequence of the processes of yield-formation.

In grain crops, the process of yield-formation may be divided into the following three phases:

1) Formation of organs for nutrient absorption and photosynthesis,

2) Formation of flower organs and "yield-container," and

3) Production, accumulation and translocation of "yield-contents." The effect of nitrogen, which has been quite popularly used to promote the growth of crop plants, also will be expressed through these processes.

In the following presentation, an attempt has been made to demonstrate the pattern and meaning of physiological responses of crop plants, especially of rice plants (Oryza sativa L.), to nitrogen as associated with their grain production, putting emphasis on the second and third phases.

\section{NITROGEN AND FORMATION OF "YIELD-CONTAINER"}

\section{A. The Number of Spikelets and Nitrogen}

According to Matsushima (1957), an upper limit of kernel growth is imposed in rice plants by the size of hulls which is determined already 1 week before heading (flowering). Thus, the "physical" capacity 
for grain yield which can be broken down into the following three components is determined at a comparatively early stage of growth:

$\begin{aligned} & \text { Capacity of } \\ & \text { "yield-container" }\end{aligned}=\left(\begin{array}{l}\text { Number of } \\ \text { panicles per } \mathrm{m}^{2}\end{array}\right) \times\left(\begin{array}{l}\text { Number of spike- } \\ \text { lets per panicle }\end{array}\right) \times\left(\begin{array}{l}\text { Size of } \\ \text { hull }\end{array}\right)$.

The number of panicles is determined by about 10 days after the maximum-tiller-number stage, and the number of spikelets per panicle, by about 10 days before flowering.

According to Kumura (1956a), there is a very close correlation between the number of spikelets per panicle and the average nitrogen content of leaf blades during the 1-4 week period before flowering. In this connection Matsushima (1957) observed that, during the process of spikelet-formation, some of the differentiated spikelets degenerated. The degeneration occurred at the stage of reduction division of pollen mother cells. It was also found that both differentiation and degeneration were quite sensitive to outside conditions-especially nitrogen supply and solar radiation-the most sensitive period for nitrogen supply being 30-32 days before flowering and for solar radiation, 15-16 days before flowering.

Yamada et al. (1957) dealt with this problem at the stand level and found close correlations between the number of spikelets per hill and the total nitrogen content of the top at flowering. Wada and Matsushima (1962) found that in a number of their experiments, the amount of total nitrogen absorbed by the end of the spikelet-differentiation stage (17-18 days before flowering) had the closest correlation with the number of differentiated spikelets per hill (Fig. 11-1), whereas the amount of

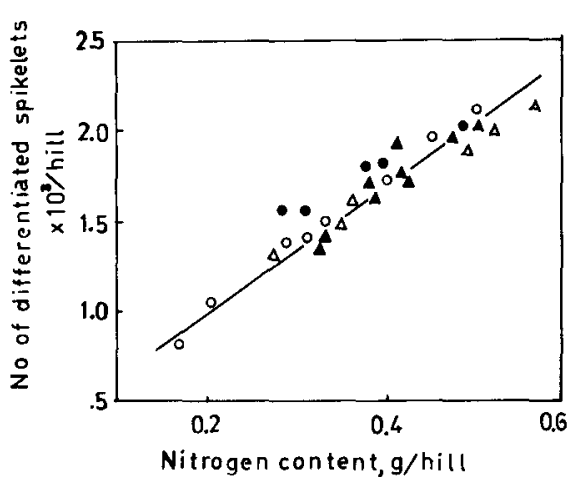

Fig. 11-1-Effect of total nitrogen content in the shoot at the late spikeletdifferentiation stage on the number of differentiated spikelets in rice plants (Wada and Matsushima, 1962). Various plots differing in variety, transplanting date, $\mathrm{N}$ level, and shaded period are included.



Figure 11-2-Effect of the amount of carbohydrate per differentiated spikelet during the late spikelet-differentiation stage to flowering on the number of degenerated spikelets (Wada and Matsushima, 1962). Plots same as in Fig. 11-1. 
carbohydrate-increase per differentiated spikelet during the period from spikelet-differentiation to flowering, showed the highest, negative correlation with the number of degenerated spikelets (Fig. 11-2).

Thus, it was established that the differentiation of spikelets was strongly promoted by nitrogen supply and their degeneration was effectively prevented by carbohydrate supply. However, as the number of degenerated spikelets is comparatively smaller than that of differentiated spikelets, the final number of spikelets usually is closely correlated with the amount of total nitrogen absorbed up to the flowering stage (Wada, 1969).

\section{B. Effect of Nitrogen Topdressing for Increasing the Capacity of "Yield-Container"}

Judging from the above-entitled results, it may be obvious that the main effect of the nitrogen topdressing applied at 3-4 weeks before heading (so-called "panicle fertilizer," widely used in Japan), lies in increasing the number of spikelets. However, it is possible that the "panicle fertilizer" is also effective in increasing the size of hulls.

Recently, a new nitrogen application method called "deep-layerapplication," in which nitrogen fertilizer is injected into a depth of 10$12 \mathrm{~cm}$ at a time about 30-40 days before heading, is gaining popularity in northern Japan with increased grain yields (Wada and Kudo, 1965). Matsuura, Iwata, and Hasegawa (1969) very recently have shown, as is indicated in Table 11-1, that this method is quite effective in increasing the size of hulls, thereby increasing the 1,000-grain weight proportionally, and that this effect is due to the promotion of net assimilation rate (NAR) caused by the nitrogen thus applied.

\section{The Number of Spikelets and LAI}

As previously described, the number of spikelets per unit area has a close correlation with the amount of nitrogen absorbed up to heading stage. As this amount of nitrogen may be considered to be nearly proportional to the leaf area index (LAI) at the heading stage, it naturally

Table 11-1-Effect of "deep-layer-application" of nitrogen topdressing on the 1,000-weight of husks and kernels and NAR (Matsuura et al., 1969)

\begin{tabular}{|c|c|c|c|c|c|c|c|c|}
\hline \multirow[b]{3}{*}{ Plot } & & & \multirow{3}{*}{$\begin{array}{l}\text { Planting } \\
\text { density } \\
\mathrm{h} 11 \mathrm{ll} / \mathrm{m}^{2}\end{array}$} & \multicolumn{4}{|c|}{1,000 weight of } & \multirow{3}{*}{$\begin{array}{l}\mathrm{NAR} \\
\mathrm{g} / \mathrm{m}^{2} \\
\text { day } \ddagger\end{array}$} \\
\hline & \multicolumn{2}{|c|}{$\begin{array}{l}\text { Nitrogen } \\
\text { supplied as }\end{array}$} & & \multicolumn{2}{|c|}{$\begin{array}{l}\text { Husks } \\
\text { attached to }\end{array}$} & \multicolumn{2}{|c|}{$\begin{array}{l}\text { Kernels } \\
\text { attached to }\end{array}$} & \\
\hline & Basal & $\begin{array}{c}\text { Top } \\
\text { dressing }\end{array}$ & & $\begin{array}{c}\text { Primary } \\
\text { rachis }\end{array}$ & $\begin{array}{l}\text { Secondary } \\
\text { rachis }\end{array}$ & $\begin{array}{l}\text { Primary } \\
\text { rachis }\end{array}$ & $\begin{array}{l}\text { Secondary } \\
\text { rachis }\end{array}$ & \\
\hline Control & 80 & $20 *$ & 22.2 & $3.3 \mathrm{~g}$ & $2.9 \mathrm{~g}$ & $20.1 \mathrm{~g}$ & $18.5 \mathrm{~g}$ & 5.7 \\
\hline "Deep" 1 & 50 & $50 \dagger$ & 22.2 & 3.7 & 3.3 & 21.7 & 19.9 & 6.8 \\
\hline "Deep" 2 & 50 & $50 \dagger$ & 29.7 & 3.9 & 3.4 & 23.0 & 20.7 & 7.8 \\
\hline "Deep" 3 & 50 & $50 \dagger$ & 29.7 & 3.9 & 3.8 & 22.8 & 21.6 & 9.9 \\
\hline
\end{tabular}

* Applied at the soll surface. $\dagger$ Applied at $10-12 \mathrm{~cm}$ deep. $\$$ NAR: Average value for the ear-initiation to heading. 


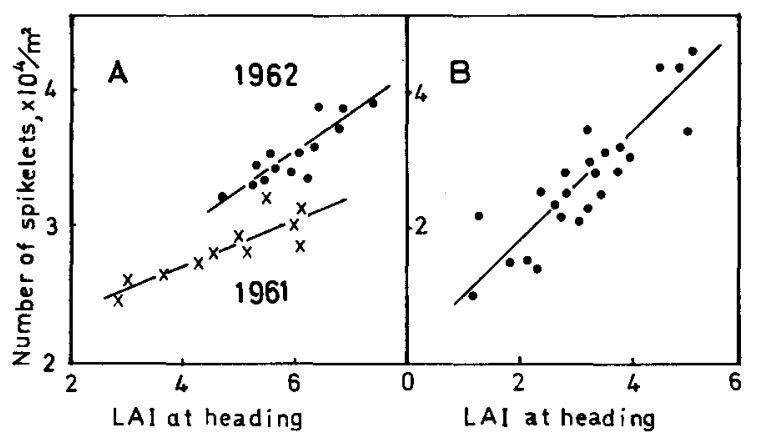

Fig. 11-3-Two examples for close correlation between LAI at flowering and the number of spikelets per area. (A) Plots of various combinations in plowing depth, planting density, and $\mathrm{N}$ level are included (Murata et al., 1966). (B) Plots of various seasons of culture are included (Tokaikinki Exp. Sta., 1967).

follows that quite high, positive correlations are observed between LAI and the number of spikelets (Fig. 11-3). The example shown here indicates that the relationship may vary considerably according to the year. Comparison of experimental conditions between the two years revealed that the factor most probably responsible was the difference in the average temperature (2.8C lower in 1962 than in 1961) during the 1-month period prior to heading when differentiation and development of spikelets took place.

On the other hand, Murayama (1967) recently has found that the nitrogen-spikelet number relationship differs according to the area of production (Fig. 11-4). The data indicate that in northern districts more spikelets are formed than in the southern districts at the same nitrogen level. Rice plants grown in northern districts contain more nitrogen and pass their ear-initiation stage under lower temperatures than those grown in southern districts (Ishizuka and Tanaka, 1956a,b; Yamada, 1963; Yanagisawa and Takahashi, 1964). From these results it may be concluded that in southern districts, rice plants tend to have

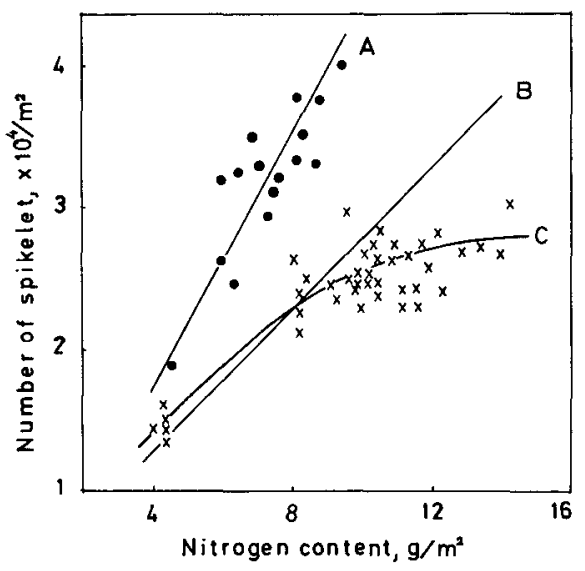

Fig. 11-4-Relationships between the amount of nitrogen contained in plants at heading and number of spikelets per area (Murayama, 1967). (A) Northern Japan (Hokkaido Exp. Sta., 1965). (B) Middle Japan (Experimentally obtained line by Shimizu, 1967). (C) Southern Japan (Kyushu Exp. Sta., 1961). 
a larger leaf area but a smaller number of spikelets, so that they must contend with more severe mutual shading than in northern districts, to insure the same capacity for yield.

\section{Fertilization (Pollination) and Nitrogen}

It is by fertilization (pollination) that spikelets are given the "accepting ability" for carbohydrates and other food material. In the case of a japonica rice, the occurrence of sterile paddy due to failure of fertilization usually amounts to no more than several percent. When, however, a heavy dose of nitrogen is applied, especially in combination with weak light, sterility of spikelets is greatly increased as was demonstrated by Togari and Kashiwakura (1958) (Fig. 11-5). They found the cause to be in the reduced number of germinated pollen at the stigma (Fig. 11-6), and this in turn was attributed to the increased occurrence of incomplete dehiscing of anthers and abnormal behavior of filaments at the time of flowering.

In indica rice which is believed to have a higher sterility percentage than japonica rice, it was found that the sterility was closely correlated with the degree of nitrogen-response. According to the work of Ota and Yamada (1965) in Ceylon, heavy doses of nitrogen fertilizer greatly increased the sterility percentage, sometimes to almost $100 \%$, in a low nitrogen-response variety, whereas the increase was far smaller in a high nitrogen-response variety.

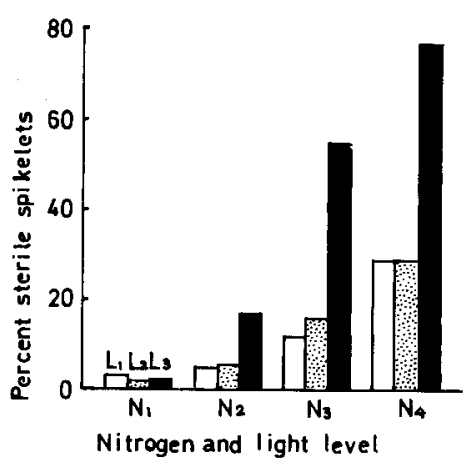

Fig. 11-5-Effect of nitrogen-fertilizer and light intensity on sterility of rice (Togari and Kashiwakura, 1958). $\mathrm{N}_{1}$ $=37.5, \mathrm{~N}_{2}=94, \mathrm{~N}_{3}=150, \mathrm{~N}_{4}=300 \mathrm{~kg} /$ ha; $\mathrm{L}_{3}=$ strongly shaded, $\mathrm{L}_{2}=$ weakly shaded, $L_{1}=$ nonshaded.



Fig. 11-6-Effect of nitrogen-fertilizer and light intensity on the number of pollens germinated on the stigma (Togari and Kashiwakura, 1958). Plots same as in Fig. 11-5. 


\section{THE AMOUNT OF "CONTENTS" IN RELATION TO THE CAPACITY FOR YIELD}

When the "capacity" for yield has been determined and pollination has been smoothly performed, the next problem is the extent to which the "container" will actually be filled.

As for the quantitative relation between the capacity of the "container" (V) and the amount of "contents" produced (C), three cases are possible: (i) $\mathrm{V}<\mathrm{C}$, (ii) $\mathrm{V}>\mathrm{C}$, and (iii) $\mathrm{V}=\mathrm{C}$. The capacity can be expressed by the product of the spikelet number, $S$, and the average size of hull. The variation due to different conditions is generally far greater in the former than in the latter. It follows, therefore, that $\mathrm{V}$ can be roughly represented by $S$. Thus, the first case occurs when $S$ is very small. Here, close correlations are usually found between grain yield, $\mathrm{Y}$, and $\mathrm{S}$, but no correlation, between $\mathrm{Y}$ and the percentage of filled grains, F, as is shown in Fig. 11-7A and 7B. This is because $Y$ is limited by the capacity of the container.

The second case is observed when $\mathrm{S}$ is extremely large. Here $\mathrm{Y}$ is usually closely correlated with F, but not with S (Fig. 11-7C and 7D). In this case, the contents limit the yield.

The third case is observed when the capacity and contents are in good harmony, so that a high $F$ value is obtained in spite of a large $S$ value. Close correlations are observed between $\mathrm{Y}$ and $\mathrm{S}$ (Fig. 11-8), as in the first case.

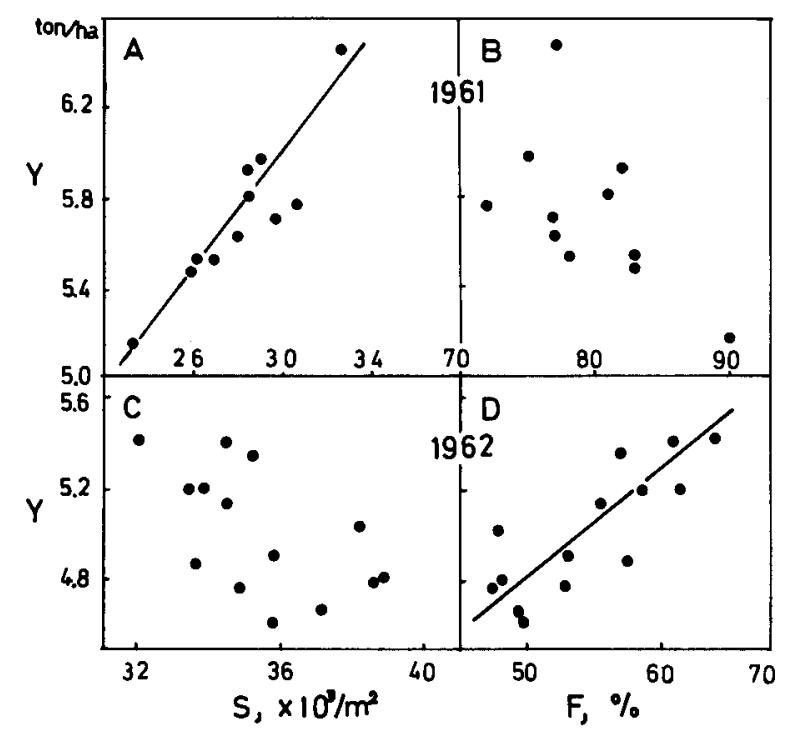

Fig. 11-7-Relationships of brown rice yield, $Y$, to the spikelets number, $S$, and the percentage of completely filled grains, F, of rice plants cultured under various combinations of plowing depth, planting density, and nitrogen level (Murata et al., 1966). 
Fig. 11-8-Relation between brown rice yield, $\mathrm{Y}$, and spikelet number, $\mathrm{S}$, in rice plants cultured in different seasons (Kyushu Agr. Exp. Sta., 1967).



These principles have been established by many experiments in Japan starting from the work of Kumura (1956a) which will be explained later. The existence of such a simple principle is largely due to the characteristics of rice plants whose grain yield is very likely to be limited by the capacity of "container." On this point, it is not likely that in wheat (Triticum aestivum L.) and corn (Zea mays L.), for example, such a severe "physical"limitations will exist,judging from the morphological structure of their grain. The following facts may be a reflection of these circumstances: In some varieties of wheat a yearly deviation of as high as $50 \%$ in 1,000-grain weight is cited by Thorne (1965), while in rice plants the deviation seldom exceeds $10 \%$.

\section{PRODUCTION OF RESERVE SUBSTANCES, RIPENING, AND NITROGEN}

\section{A. Accumulation of Organic Substances and Nitrogen}

According to the works of Togari, Okamoto, and Kumura (1954), Togari and Sato (1954), Murayama et al. (1955), Soga and Nozaki (1957), and others, the following patterns were observed in the production and accumulation of organic substances in rice plants (Fig. 11-9). At early stages, protein synthesis is most active and this is immediately followed by accumulation of cell wall substances such as lignin and cellulose. In close succession to this, accumulation of hemicellulose takes place, while accumulation of sugars and starch begins at intermediate stage of growth and becomes dominant at later stages. The accumulation of starch and sugars usually begins in culms and leaf sheaths at around the ear-initiation stage, which is about 30 days before flowering. The highest content is reached at the flowering stage. (Fig. 11-9B). Immediately after flowering, translocation of the temporarily reserved carbohydrates to the panicles begins. The grain makes a rapid growth under the influence of both the stored, and currently synthesized, carbohydrates.

Being one of the most important constituents of proteins, nitrogen always gives a marked, promoting influence on protein synthesis. On 


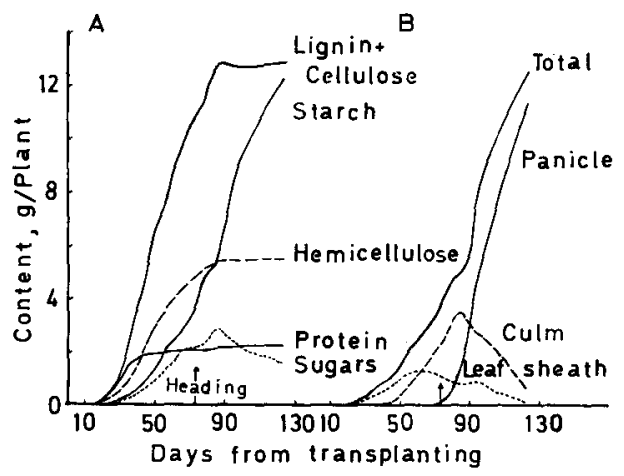

Fig. 11-9-Changes in various organic substances in rice plants according to growth stage (Togari et al., 1954). (A) Various organic substances. (B) Starch content in various organs.

the other hand, nitrogen produces a complex influence on carbohydrate metabolism: Sometimes it remarkably promotes the production of carbohydrates, but on other occasions it greatly reduces carbohydrate accumulation. At the elongation stage of rice plants, the content of total nitrogen and protein-nitrogen increases with increasing supply of nitrogen, while the content of sugars and starch drastically decreases (Table 11-2).

It is a widely recognized fact that in rice plants the smaller the nitrogen supply at the heading stage, the greater is the carbohydrate accumulation (Fujiwara et al., 1951; Takahashi et al., 1957; Matsushima, 1957; and others). The same situation is recognized also in some other species, for example, in orchardgrass (Griffith, Teel, and Parker, 1964; Colby et al., 1965; Auda et al., 1966) and coastal bermudagrass (Adegbola and McKell, 1966).

Large differences in effect were induced by varying the time and combination of nitrogen application, as is shown in Fig. 11-10. Thus, the nitrogen applied at the earlier stage of growth is always effective in increasing the carbohydrate accumulation at maturity, but the nitrogen applied at the later stage of growth is effective only when the level of nitrogen at the earlier stage is not too high. These effects may be

Table 11-2-Composition of the leaf blade and stem of rice plants at the elongation stage under different levels of nitrogen supply (Takahashi et al., 1955)

\begin{tabular}{|c|c|c|c|c|c|c|c|c|}
\hline \multirow[b]{3}{*}{ Composition } & \multicolumn{8}{|c|}{ Plant part } \\
\hline & \multicolumn{4}{|c|}{ Leaf blade } & \multicolumn{4}{|c|}{ Stem (sheath and culm) } \\
\hline & $\mathrm{N}_{0}$ & $\mathrm{~N}_{1}$ & $\mathrm{~N}_{3}$ & $\mathrm{~N}_{5}$ & $\mathrm{~N}_{0}$ & $\mathrm{~N}_{1}$ & $\mathrm{~N}_{3}$ & $\mathrm{~N}_{5}$ \\
\hline Total N & 1.93 & 2. 38 & 3. 15 & 3.61 & 0.91 & 0.88 & 1.49 & 1.74 \\
\hline Protein & 1.68 & 2. 09 & 2. 74 & 3.14 & 0.73 & 0.68 & 1,21 & 1. 34 \\
\hline Total sugars & 6.05 & 5.24 & 5.30 & 4.61 & 3.79 & 4.04 & 3. 15 & 1. 52 \\
\hline Starch & 5. 16 & 2.34 & 4.69 & 3. 78 & 12.10 & 12.90 & 7.50 & 3.60 \\
\hline
\end{tabular}

Notes: $N_{0}-$ No nitrogen; $N_{1}-37.5 \mathrm{~kg}$ nitrogen; $\mathrm{N}_{3}-113 \mathrm{~kg}$ nitrogen; $\mathrm{N}_{5}-188 \mathrm{~kg}$ nitrogen/ha. 
Fig. 11-10-Effect of the amount and time of nitrogen application on the carbohydrate accumulation at maturity in rice plants (Kumura, 1956b). Plot name, e.g., $2 \mathrm{~N}-2 \mathrm{~N}$ means two times normal level of nitrogen applied before heading, and the same amount applied after heading.

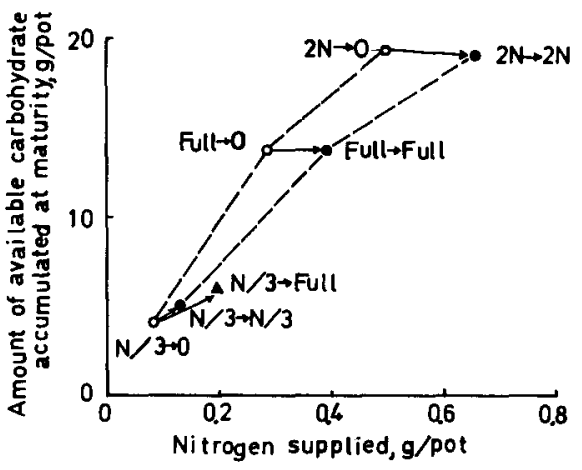

explained from the fact that the earlier application primarily promotes leaf area expansion, while the later application stimulates the photosynthetic activity of the leaf as well as preventing the decline of leaf area (Murata, 1961).

Generally speaking, nitrogen topdressing after the spikelet-differentiation stage increases carbohydrate accumulation both at heading and at maturity (Sato, 1956; Wada, 1969). After this stage, the growthstimulating effect of nitrogen greatly decreases.

\section{B. Ripening and Nitrogen}

Kumura (1956b) found in a pot experiment an interesting relationship between the $\mathrm{C} / \mathrm{S}$ ratio-the ratio of the amount of total availak?e carbohydrates (sugars plus starch) accumulated in plants at maturity, $\mathrm{C}$, to the total number of spikelets, $\mathrm{S}$-and the distribution ratio, $\mathrm{C}_{\mathrm{E}} / \mathrm{C}$, (the ratio of the amount of carbohydrates accumulated in the ears, $\mathrm{C}_{\mathrm{E}}$, to $\mathrm{C})$ as is shown in Fig. 11-11. The data indicate that when the C/S ratio is small under high nitrogen level, almost all of the carbohydrates

Fig. 11-11-Relationship between the amount of carbohydrate at maturity per spikelet $(\mathrm{C} / \mathrm{S})$ and its distribution rate to ears $\left(\mathrm{C}_{\mathrm{E}} / \mathrm{C}\right)$ in rice plants supplied with various amount of nitrogen $(\mathrm{Ku}-$ mura, $1956 \mathrm{~b}$ ).




accumulated in the plant are translocated to the ear, so that the distribution ratio becomes nearly $100 \%$. When the $\mathrm{C} / \mathrm{S}$ ratio is large under low nitrogen level, the carbohydrates in excess of the capacity of the grains remain in the straw, and as a result the distribution ratio decreases. In the former case, as was mentioned earlier, grain yield is limited by the amount of carbohydrates produced, and in the latter case, by the number of spikelets.

Also Matsushima (1957) showed in field experiments that the smaller the basal dose of nitrogen, the larger the effect of topdressing on the percentage of filled grains and 1,000-grain weight. Thus, the degree of filling of grains is determined basically by the ratio between the number of spikelets and the total amount of carbohydrates accumulated at the time of maturity.

\section{Photosynthetic Activity, Respiratory Activity, and Nitrogen}

As to the effect of nitrogen in promoting or maintaining the photosynthetic activity as well as respiratory activity, there are already sufficient data, especially in rice plants, since the work of Mitsui and Ishii $(1938,1939)$ (c.f. Murata, 1965). Recently other results have been added by Osada (1964, 1966), Osada and Murata (1965a,b), Murata et al. (1966), and Tanaka, Kawano, and Yamaguchi (1966). Also in other species, for example, soybean (Ojima, Fukui, and Watanabe, 1965), and sweet potato (Tsuno and Fujise, 1965), results similar to those with rice have been obtained. Based upon the work with rice, photosynthetic activity measured under normal conditions has a very close, positive correlation with the total or protein nitrogen content of the leaf over a wide range, usually up to $5 \%$ nitrogen, irrespective of the growth stage, as is shown in Fig. 11-12. Fujiwara and co-worker found that in developing rice leaves the photosynthetic activity was proportional to the nitrogen content corrected by subtracting the nitrogen content of the very young leaf which had, as yet, no photosynthetic capacity (Fujiwara, 1965).



Fig. 11-12-Relation between $\mathrm{N}$ content and photosynthetic activity of the rice leaf (Murata et al., 1966). Leaves were sampled from those plants grown in the field under various combinations in plowing depth, planting density, and nitrogen level and measured under saturating light intensity and normal $\mathrm{CO}_{z}$ concentration. 
On the other hand, higher nitrogen supply does not always bring about higher photosynthetic activity, though the photosynthetic capacity of the plant or stand may be greatly enhanced (Murata, 1961). This is because, under high nitrogen supply, growth and development of leaves are greatly stimulated, so that the nitrogen content of each leaf is 'diluted,' making the difference of nitrogen content comparatively small, and increasing the possibility of relative deficiency in other nutrients. If, however, nitrogen is applied at a stage when the growth of leaves is slowed down or stopped due to a certain inner or outer condition, then photosynthetic activity will be stimulated in most cases. Herein lies the reason for the typical effect of nitrogen topdressing applied at later growth stages (Murata, 1961).

In higher plants, chloroplasts account for $25 \%$ of the total dry weight, and $40 \%$ of the total nitrogen, of the leaf (Bonner, 1952). About $50 \%$ of the dry weight of the chloroplast is composed of various proteins. The stroma protein, responsible for reduction of $\mathrm{CO}_{2}$ makes up about one-third of the protein of the chloroplast. The remaining twothirds consists of the structural proteins responsible, in combination with chlorophyll, for the primary processes in photosynthesis (Menke, 1966). Although little information is available, it is supposed that the effect of nitrogen on photosynthetic activity is basically exerted through the metabolism of these chloroplast proteins and chlorophyll. According to Bourdu et al. $(1965,1966)$, not only decreases in the content of chlorophyll and protein but also changes in structure and function of chloroplast were observed in the nitrogen-deficient Bryophyllum leaf. The chloroplasts were filled with large starch inclusions which disorganized the lamellar system, some chloroplasts were membraneless, and Hill-reaction and photophosphorylation activities were very low.

Nitrogen also affects photosynthesis in another way. Navasero and

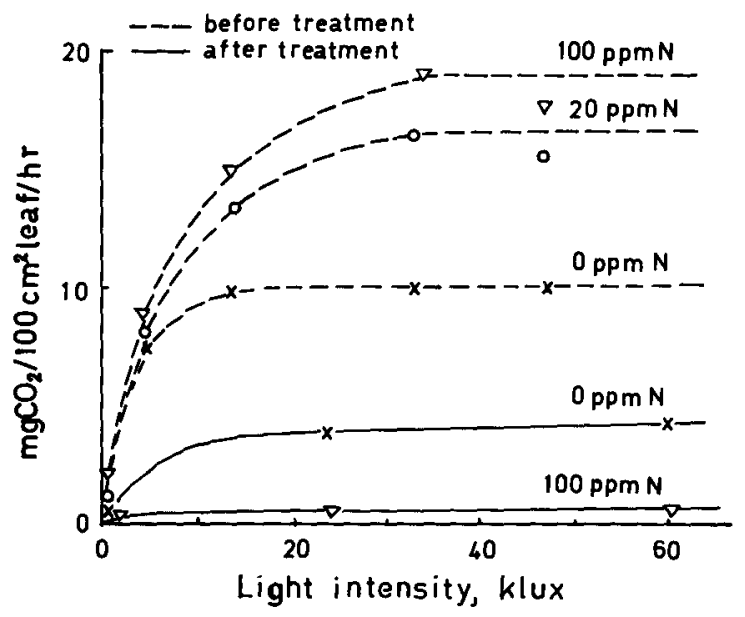

Fig. 11-13-Photosynthetic rate at different light intensities of 'Peta' leaves before and after a 13-day, 400 lux dark treatment (Tanaka et al., 1966). The respiratory rates in $\mathrm{mg} \mathrm{CO} / \mathrm{dm}^{2}$ per hr were: before-0 $\mathrm{N}=0.757,20 \mathrm{~N}=$ $1.004,100 \mathrm{~N}=1.807 ;$ after $-0 \mathrm{~N}=0.84$, and $100 \mathrm{~N}=0.86$. 
Tanaka (1966) have made the very interesting observation that when rice plants supplied with abundant nitrogen were kept under a reduced light condition (400 lux) for 13 days, their leaves completely lost photosynthetic activity, but retained respiratory activity, as is shown in Fig. 11-13. This finding could explain one of the common causes for the death of lower leaves of plants under heavy mutual shading: Lack of respiratory substrates induces protein breakdown, as is shown in Table 11-3, leading to the production of amino acids, amides, and ammonium ion which is toxic to the cell and eventually kills the leaves.

\section{Root Activity and Photosynthetic Activity}

A close correlation between nitrogen content and photosynthetic activity is not found in cases where root injury is probable, for example, in a poorly drained, strongly reduced soil (Murata et al., 1966). Here, two problems are involved. One is the influence of toxic substances produced in the soil, and the other is the role of the root for maintaining the photosynthetic activity.

Concerning the first problem, Baba and Tajima (1962) and Yanagisawa and Takahashi (1964) observed that addition of hydrogen sulfide to the culture medium reduced the photosynthetic activity of rice leaves, and caused an abnormal acceleration of respiration and decreased absorption of nutrients. As to the second problem, Murata, Iyamm, and Honma (1965) demonstrated a close interdependence between root activity and photosynthetic activity in water-cultured rice plants. The root system was subjected to various unfavorable conditions such as addition of hydrogen sulfide or ferrous iron into the solution, depletion of oxygen from the solution, and others. After a few days considerable differences developed in the p rotein content of the leaf, though the plants were uniformly kept without added nitrogen supply. The difference in protein content was clearly associated with changes in photosynthetic activity as is shown in Fig. 11-14.

That the presence of the root is closely correlated with the protein level of the shoot has been shown by Chibnall (1954), Mothes and Engel-

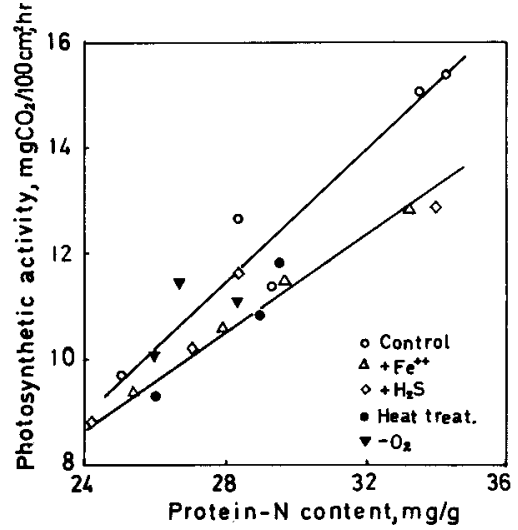

Fig. 11-14-Relationships between protein-nitrogen content of the leaf and photosynthetic activity in rice plants given various treatments to the root (Murata et al., 1965). 
brecht (1956), Oritani (1963), Oritani and Yoshida (1967) and others. On the other hand, evidence is now accumulating indicating the necessity of simultaneous synthesis of ribonucleic acids (RNA) for protein synthesis (McKee, 1962). In plants without roots, the ability to synthesize RNA decreases, followed by reduced protein synthesis (Togari and Oritani, 1960; Oritani, 1963). These facts suggest the possibility that the root may in some way influence RNA synthesis and thereby control the protein level of the leaf, and as a result may influence photosynthetic activity.

\section{DRY MATTER AND GRAIN PRODUCTION UNDER ABUNDANT NITROGEN SUPPLY}

This topic will be discussed both from the standpoint of direct effect of heavy doses of nitrogen on the plant itself, and from the standpoint of indirect influence of the environment which the plants have created under such conditions.

\section{A. Disruption of Photosynthesis-Respiration Balance}

With the advance of growth from the initial stage dominated by differentiation to the stage of rapid growth, the demand for carbohydrates increases, and therefore, the problem of keeping the balance between photosynthesis and respiration ( $P-R$ balance) becomes increasingly important. The LAI of a rice stand reaches its maximum a little before heading. In order to hasten the expansion rate of LAI and enlarge the "capacity" for yield, a heavy application of nitrogen at an early stage is quite effective. On the other hand, such an application is very likely to deteriorate the P-R balance of the crop stand, adversely affecting the accumulation of carbohydrates and grain-filling.

The existence of an optimum leaf area for the maximum dry matter production of a plant community was shown theoretically by Monsi and Saeki (1953), and experimentally by Takeda (1961), Murata (1961) and Tanaka et al. (1966) in rice stands. These authors also demon-

Fig. 11-15-Relationship between dry matter increase before $\left(\Delta W_{1}\right)$ and after heading $\left(\Delta W_{2}\right)$ in rice plants grown in the field under various combinations of plowing depth, planting density, and nitrogen level (Murata et al., 1966).




strated that one of the fundamental, physiological causes responsible for various difficulties occurring under an abundant supply of nitrogen lies in the deterioration of P-R balance due to increased mutual shading. Thus, under these conditions, a phenomenon occurs such as that reported by Murata et al. (1966) and Tanaka et al. (1966) in which the more vigorous the growth of the stand before heading stage, the smaller is the dry matter increase in the grain-filling stage. (Fig. 11-15).

\section{B. Influence of Solar Radiation on Nitrogen Effect}

The disruption of $\mathrm{P}-\mathrm{R}$ balance of crop stands due to heavy application of nitrogen is intensified under conditions of low solar radiation. Murata (1961) observed that in some extreme cases those plants supplied with high rates of nitrogen temporarily lost dry weight when the solar radiation was very poor (approximately $200 \mathrm{cal} / \mathrm{cm}^{2} / \mathrm{day}$ ) at around the heading stage. Wada (1969) has recently concluded from a number of his experiments (Fig. 11-16) that dry matter increase in rice during the ripening period is most closely correlated with the following product: $(\mathrm{N}+\Delta \mathrm{N}) \mathrm{Q}$, where $\mathrm{N}$ stands for the total nitrogen content of leaves at heading, $\Delta \mathrm{N}$ for the amount of nitrogen absorbed during the filling period, and $Q$ for the average solar radiation during the same period. Chernavskaya and Nichiporovich (1966) also have concluded from many data that, when nitrogen supply and light level are within the



Fig. 11-16-Relation between dry matter increase after heading and the product of the amount of solar radiation (Q) and the sum of nitrogen content in leaf blade (N) and the amount of nitrogen absorbed after heading $(\Delta N)$ in rice plants (Wada, 1969). Various plots differing in time of culture, degree of shading, $\mathrm{N}$ level, and year are included.



Fig. 11-17-Rough rice yield at different light intensities and nitrogen fertility (Stansel et al., 1965). 
range of "harmonious combination," the efficiencies of photosynthesis, growth, and dry matter production are highest.

In the case of grain production, another circumstance adds to the importance of solar radiation during the filling period. Grain-filling depends almost entirely upon the currently produced carbohydrates under a heavy nitrogen application as was shown by Murayama et al. (1955). Also, Stansel et al. (1965) found, as is shown in Fig. 11-17, that the higher the radiation level during the critical 6 weeks -3 weeks before heading plus 3 weeks after it-the larger was the effect of nitrogen on the grain yield of rice.

\section{Disturbance of Nitrogen Metabolism}

An abundant supply of nitrogen can stimulate growth as long as there are sufficient supplies of growth hormone(s), carbohydrates, water and other nutrients as well as environmental conditions suitable for rapid growth. At present we do not know the exact mechanism for the growth process. However, it is clear that growth which is stimulated by nitrogen supply is inseparably combined with protein synthesis which is carried out at the expense of carbohydrates in reserve or currently under production. Ther efore, if nitrogen supply is too abundant in comparison to the rate of carbohydrate production, plants will sooner or later be depleted of carbohydrate reserve. Such plants will face the danger of ammonium toxicity, having insufficient carbohydrates to promote the conversion of ammonium to amides or amino acids. To make the situation worse, in paddy soil which is in a highly reduced state under flooded water, most of the available nitrogen is in the form of the ammonium ion. Thus, the possibility of severe ammonium toxicity for rice plants is expected from the highest-tiller-number stage through the heading stage. Carbohydrate accumulation is still very small during this time. A large increase in the content of ammonium ion and amides in the cells of rice plants supplied with a topdressing of ammonium sulfate was demonstrated by Ito and Sakamoto (1942) and this was considered as an important causal factor for the increased susceptibility of rice plants to the blast disease. In lower leaves, increase of soluble nitrogen due to protein degradation is also expected (c.f. Table 11-3).

Another problem to be considered here is the disturbance of nitrogen metabolism following decreased nitrate reductase activity under shaded conditions. This problem has recently been actively studied by Hageman and Flesher (1960), Hageman, Flesher, and Gitter (1961),

Table 11-3-Nitrogen in various fractions in leaves of rice grown in the dark for 7 days compared to that grown in the light (Navasero and Tanaka, 1966)

\begin{tabular}{ccc}
\hline & \multicolumn{2}{c}{ Content, mg/g fresh wt } \\
\cline { 2 - 3 } Nitrogenous fractions & Control & Dark \\
\hline Ammonium-N & .09 & .34 \\
Amino-N & .68 & 3.04 \\
Amide-N & .14 & .36 \\
Protein-N & 11.64 & 8.08 \\
\hline
\end{tabular}


Knipmeyer et al. (1962), Beevers et al. (1965), Harper and Paulsen (1967), and others, in corn, wheat and other species. Knipmeyer et al. (1962), studying three corn hybrids which were artificially shaded or placed under competitive plant shading, observed increased nitrate accumulation in spite of unchanged total nitrogen content. They concluded that nitrogen metabolism was more adversely affected by shading than was carbohydrate metabolism. This conclusion has led them to denial of the common idea that nitrogen metabolism is limited by carbohydrate metabolism under such conditions.

The same situation is expected under heavy mutual shading caused by abundant nitrogen supply. Thus, a large amount of nitrate accumulation is reported in grasses. However, the ability to store nitrogen as nitrate differs greatly from species to species, being high in such plants as sugar beet, tobacco, wheat, and soybean (McKee, 1962), and very low in rice plants, at least when grown with ammonium nitrogen (Izawa, Oji, and Okamoto, 1966; etc.). Many upland crops accumulate nitrate which is far less harmful than ammonium for the plant, thus they can store a considerable amount of nitrogen without consuming carbohydrates. In contrast to this, it is inevitable for rice plants to consume stored carbohydrates to avoid the toxic effect of ammonium under heavy nitrogen supply. That is to say, in rice plants nitrogen metabolism is quite closely combined with, and likely to be limited by, carbohydrate metabolism, whereas in many upland species nitrogen metabolism is more or less loosely combined with, and to some extent independent of , carbohydrate metabolism due to the ability of the plants to store nitrates.

\section{Decrease of Root Activity}

The root system of a plant requires adequate supplies of carbohydrates and other nutrients to maintain its activity. Under stand conditions in the field, root activity is quite often limited by carbohydrate supply from the shoot. Thus, Thomas and Hill (1949) observed in alfalfa that the daily change of root respiration quite closely resembled a 3day running average of net assimilation. Such a situation may become serious under an abundant supply of nitrogen.

According to the studies of Tanaka (1958) in rice, division of work is seen concerning the carbohydrate supply among the leaves different in their position on the stem; upper leaves supply carbohydrates to the developing new leaves and ears, while lower leaves supply the root system. This observation was also reported in bean (Biddulph and Cory, 1965), field pea (Pate , 1966), and tobacco (Tokitsu et al., 1957). As was mentioned earlier, under heavy nitrogen supply, lower leaves are very likely to die due to carbohydrate deficiency. Thus, the root system loses both activity for nutrient absorption and also resistance to toxic substances in the soil. Root rot develops, in turn the death of lower leaves intensifies (Okajima, 1960; Baba, 1961), and the photosynthetic activity of the remaining leaves decreases (Murata et al., 1965). According to Okajima (1960), if under such conditions nitrogen supply is temporarily suspended, the root loses oxidative activity and as a result turns the surrounding medium to a more reduced state, intensifying the 
production of hydrogen sulfide. However, according to recent work of Hoshino, Matsushima, and Matsuzaki (1969) such adverse effects of nitrogen-depletion can be largely eliminated by addition of small amount of nitrogen to the root media.

Tanaka et al. (1964) observed a larger dry weight increase in those rice plants which could continue absorption of nitrogen after the heading stage. Tsuno (1968) showed, in several rice varieties with which he succeeded in obtaining yields in excess of 8 tons of brown rice per hectare, that the amount of nitrogen absorbed after heading was equivalent to as much as $19-78 \%$ of the nitrogen accumulated in ears at harvest. He stressed that such active absorption of nitrogen from the soil made it possible to maintain a large LAI as well as high photosynthetic activity until a very late stage, contributing greatly to the high yield.

\section{E. Translocation and Distribution of Substances and Nitrogen}

Nitrogen can affect, though indirectly, the translocation and distribution of various substances in plants. Such an influence of nitrogen is based on the fact that different parts of the plant respond to nitrogen to different degrees. For example, as is shown in Table 11-4, at a lower level of nitrogen supply, there exists a larger stimulus to the growth of root than shoot, increasing translocation of carbohydrates to the root. At a higher level of nitrogen supply, however, shoot growth is greatly stimulated and this in turn decreases the translocation of carbohydrates to the root, thereby suppressing its growth. In this way, nitrogen influences the distribution of substances among different organs.

Shimizu (1967) found that the higher the nitrogen content in the rice leaf, the larger was the portion of dry matter allotted for the formation

Table 11-4-Distribution of ${ }^{14} \mathrm{C}$ between the shoot and root of rice plant 4 days after ${ }^{14} \mathrm{CO}_{2}$ given (5th Laboratory of Physiology, Nat. Inst. Agr. Sci., 1960)

\begin{tabular}{|c|c|c|c|c|}
\hline \multirow[b]{2}{*}{$\begin{array}{c}\text { Plot } \\
\left(\begin{array}{c}\text { Amount of } \\
\text { N added }\end{array}\right)\end{array}$} & \multirow[b]{2}{*}{ Part } & \multirow[b]{2}{*}{$\begin{array}{l}\text { Dry wt } \\
\mathrm{g} / \text { plant }\end{array}$} & \multicolumn{2}{|c|}{ Amount of ${ }^{14} \mathrm{C}$} \\
\hline & & & $\begin{array}{c}\text { count } / \mathrm{min} \\
/ \mathrm{plant} \\
\times 10^{3}\end{array}$ & $\begin{array}{l}\text { Relative } \\
\text { to total }\end{array}$ \\
\hline \multirow[t]{2}{*}{$\begin{array}{c}\text { Low }-N \\
(0 \mathrm{~g})\end{array}$} & $\begin{array}{l}\text { Leaf blade } \\
\text { Leaf sheath } \\
\text { Root }\end{array}$ & $\begin{array}{l}0.91 \\
0.94 \\
0.76\end{array}$ & $\begin{array}{l}5.8 \\
2.8 \\
5.9\end{array}$ & $\begin{array}{l}40 \\
19 \\
41\end{array}$ \\
\hline & Total & 2.61 & 14.5 & 100 \\
\hline \multirow[t]{2}{*}{$\begin{array}{l}\text { Medium-N } \\
(3 \mathrm{~g} / \text { plant })\end{array}$} & $\begin{array}{l}\text { Leaf blade } \\
\text { Leaf sheath } \\
\text { Root }\end{array}$ & $\begin{array}{l}4.29 \\
3.12 \\
2.11\end{array}$ & $\begin{array}{r}15.3 \\
10.1 \\
4.7\end{array}$ & $\begin{array}{l}51 \\
34 \\
15\end{array}$ \\
\hline & Total & 9.52 & 30.1 & 100 \\
\hline \multirow[t]{2}{*}{$\begin{array}{l}\text { High-N } \\
(6 \mathrm{~g} / \text { plant })\end{array}$} & $\begin{array}{l}\text { Leaf blade } \\
\text { Leath sheath } \\
\text { Root }\end{array}$ & $\begin{array}{l}4.97 \\
3.43 \\
2.33\end{array}$ & $\begin{array}{l}19.5 \\
13.8 \\
4.2\end{array}$ & $\begin{array}{l}52 \\
37 \\
11\end{array}$ \\
\hline & Total & 10.73 & 37.5 & 100 \\
\hline
\end{tabular}

Note: ${ }^{1 /} \mathrm{CO}_{2}$ applied, $50 \mu \mathrm{c} /$ plant, for 1 hour, at the max-t1ller - number stage. 


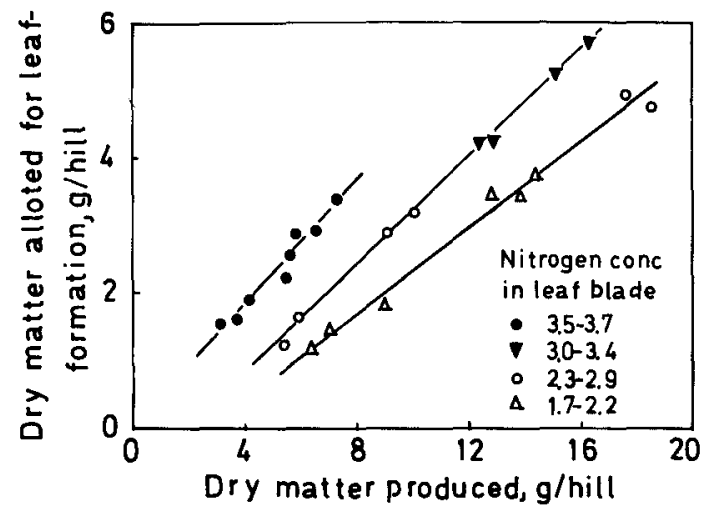

Fig. 11-18-Relationships between nitrogen conc. in leaf blade and the amount of dry matter allotted for leaf formation in rice plants (Shimizu, 1967).

of new leaves (Fig. 11-18). Interesting results were also reported by Tsuno and Fujise (1965) in the sweet potato (Ipomoea batatas L.). Here both potassium and nitrogen were shown to play important roles in determining the relative distribution of dry matter between shoot and root.

It is also possible that nitrogen can influence translocation through its effect on the development or longevity of conducting tissues. Matsushima (1957) found that the cross-sectional area of the conducting tissues of the main culm of rice plants was made considerably larger by removing all the tillers except the main culm, thereby giving a more favorable environment to the plants.

In the "deep-layer-application" of nitrogen which was mentioned earlier, the grain yield of the treated plot was higher than the control (Table 11-5), in spite of the fact that dry matter increase during the filling period was considerably smaller in the treated plot. The larger pre-heading accumulation of carbohydrates in the culm must be primarily responsible for this increased yield, but at the same time it is quite possible that not only the size of hulls but also the effectiveness of the conductive tissue facilitated the translocation of carbohydrates to the grain.

Table 11-5-Effect of "deep-layer-application" of nitrogen on dry weight increase and grain yield of rice (Matsuura et al., 1969)

\begin{tabular}{|c|c|c|c|c|}
\hline \multirow[b]{2}{*}{ Plot } & \multicolumn{2}{|c|}{ Dry weight increase } & \multirow{2}{*}{$\begin{array}{l}\text { Total avallable } \\
\text { carbohydrates } \\
\text { in culms at } \\
\text { heading }\end{array}$} & \multirow{2}{*}{$\begin{array}{l}\text { Yield of } \\
\text { brown } \\
\text { rice }\end{array}$} \\
\hline & $\begin{array}{l}\text { Before heading } \\
\text { (July } 4 \text { - July } 31 \text { ) }\end{array}$ & $\begin{array}{c}\text { After heading } \\
\text { (July } 31 \text { - Sept } 16 \text { ) }\end{array}$ & & \\
\hline & $\mathrm{g} / \mathrm{m}^{2}$ & $\mathrm{~g} / \mathrm{m}^{2}$ & $\%$ dry wt & ton $/ \mathrm{ha}$ \\
\hline $\begin{array}{l}\text { Control } \\
\text { "Deep" } 1\end{array}$ & $\begin{array}{l}736 \\
755\end{array}$ & $\begin{array}{l}454 \\
480\end{array}$ & $\begin{array}{l}6.6 \\
8.9\end{array}$ & $\begin{array}{l}6.80 \\
6.88\end{array}$ \\
\hline "Deep" 2 & 944 & 290 & 8.6 & 7.12 \\
\hline "Deep" 3 & 1,052 & 170 & 12.5 & 7.51 \\
\hline
\end{tabular}

Note: Plots are the same as in Table 11-1. 




Fig. 11-19-Promotion of photosynthetic and respiratory activity by high nitronitrogen supply in rice varieties differing in nitrogen response (Osada, 1966). Photosynthetic rate was measured under a saturating light intensity and normal $\mathrm{CO}_{3}$ conc., using excised leaves, and respiratory rate is based on values of $\mathrm{CO}_{2}$ $\mathrm{mg} / \mathrm{g}$ dry wt of the whole shoot at $28 \mathrm{C}$, both at heading stage of water-cultured plants.

\section{F. Nitrogen Response of Varieties}

According to the results of Osada and Murata $(1962,1965)$ and Osada $(1964,1966)$, high nitrogen-response varieties of rice show, under heavy nitrogen application, a larger promotion in photosynthetic activity, but a smaller promotion in respiratory activity, than do low response varieties (Fig. 11-19). Reflecting these characteristics, the $P / R$ ratio, on a field-area basis, is larger in high response varieties than in low response ones (Fig. 11-20).

Tanaka et al. (1966), on the other hand, have shown that shortness of culm is essential for high nitrogen response from the standpoint of avoiding lodging, but that it is also important in that it decreases the

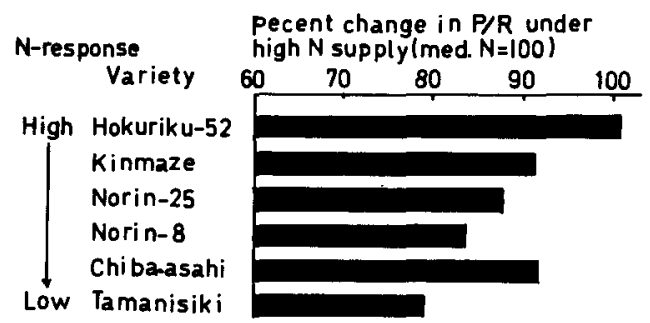

Fig. 11-20-Changes in the ratio of total photosynthesis to respiration of population $(P / R)$ by increasing nitrogen supply in rice varieties differing in nitrogen response (Osada, 1966). Nitrogen supply: High $\mathrm{N}, 150 \mathrm{~kg} / \mathrm{ha}$; med. $\mathrm{N}, 75 \mathrm{~kg} / \mathrm{ha}$. 
portion of respiration which is not directly effective for grain production. Takahashi, Iwata, and Baba (1959) showed that high response varieties accumulated, under heavy nitrogen supply, more carbohydrates than low response varieties, while nitrogen absorption at early stages of growth was more active in low response varieties than in high response ones. Tanaka et al. (1964) have proved that even low response varieties can produce a high grain yield if grown in an environment where nitrogen supply is restricted or photosynthesis is enhanced.

From these results it may be concluded that high nitrogen-response varieties tend to have higher ability for carbon assimilation in comparison to the ability for nitrogen assimilation and growth, while low response varieties tend to be superior in the ability for nitrogen assimilation and growth but somewhat inferior in their ability for carbon assimilation.

Baba (1961) mentioned, as one of the important characteristics of high response varieties, their comparatively high grain/straw ratio under heavy nitrogen supply. In relation to this problem, the speaker has very recently found an interesting phenomenon from Osada's data (1966): As shown in Fig. 11-21, there is a very clear, positive correlation between the panicle/straw ratio and the $\mathrm{P}_{0} \cdot \mathrm{S} / \mathrm{A}$ ratio, where $\mathrm{P}_{0}$ denotes the average photosynthetic activity, during the filling period of individual varieties; $\mathrm{S}$, the number of spikelets per unit area, and $\mathrm{A}$, the LAI at heading stage, respectively. Here, S/A represents the important morphological characteristics expressing the yield "capacity" relative to the thickness of the stand, as was mentioned before (c.f. Fig. 11-3). The relationship shown in Fig. 11-21 indicates that the larger the ability for carbon assimilation and the spikelet number, and/ or the smaller the LAI, the higher is the panicle/straw ratio.

Recently Ogata and Ishizuka (1967a,b,c) have studied the genetics of nitrogen-response in potato, using a cultivated species, a wild species, their hybrid, and the progeny of the second backcross to the cultivated species. As is shown in Fig. 11-22, the closer the relationship to the cultivated species, the larger is the amount of dry matter production, the growth of tubers, and chlorophyll concentration, under high nitrogen supply. However, chlorophyll concentration under low nitrogen supply was higher in the wild species. It was also found that the closer the

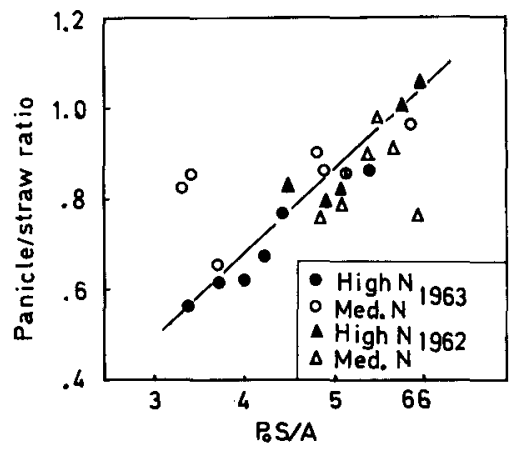

Fig. 11-21-Relationship between the panicle/straw ratio and $\mathrm{P}_{\mathrm{O}} \mathrm{S} / \mathrm{A}$ in rice varieties differing in nitrogen re sponse (Calculated from the data of Osada, 1966). $P_{o}=$ photosynthetic activity of leaf during grain-filling period. $\mathrm{S}=$ spikelet number per area, and $\mathrm{A}=\mathrm{LAI}$ at heading stage. 

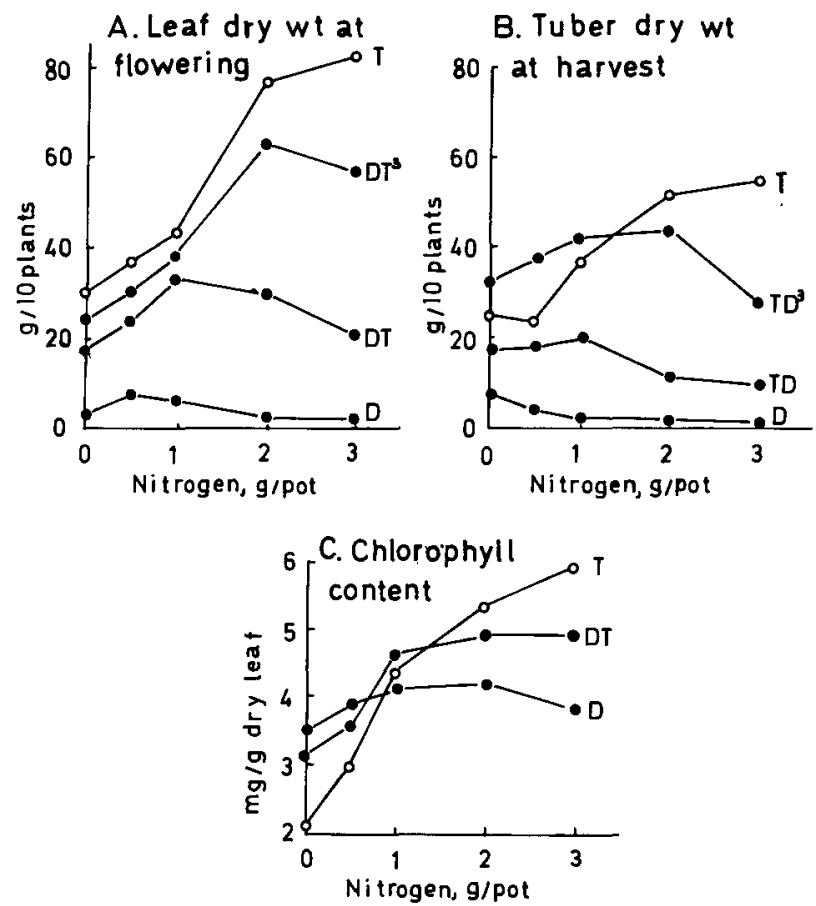

Fig. 11-22-Changes in the dry weight of leaves and tubers and chlorophyll concentration in the leaf in relation to nitrogen supply in cultivated, wild, and their hybrid potatoes (Ogata and Ishizuka, 1967). $\mathrm{T}=$ cultivated species, Solanum tuberosum; $D=$ wild species, $S$. demissum forma atrocyaneum; $D \bar{T}=$ their hybrid; and, $\mathrm{DT}^{3}=$ two-time backcross.

relationship to the wild species, the lower was the apparent photosynthetic rate and more photosynthates were turned into amides and organic acids, whereas in the cultivated species more of the photosynthates were held as compounds soluble in hot alcohol.

One may conclude that in the case of potato, the wild species is lower than the cultivated species, not only in the ratio of carbon assimilation to nitrogen assimilation, but also in the absolute level of both types of assimilation. In the case of rice varieties, on the other hand, it seems that the assimilation of both carbon and nitrogen has been greatly improved in the process of breeding, while the ratio has been left unchanged in low nitrogen-response varieties, which are useful under low nitrogen conditions.

\section{CONCLUSION}

The speaker has shown, in a limited way, the outline of the knowledge we have at present on how nitrogen affects the processes of yield formation of crop plants, using the rice plant as an example. During 
the analyses, it has been pointed out that the way in which nitrogen affects the development of an organ always follows the same principles, however morphologically different the organs may be, but that there seems to be some difference in the degree of interdependence between nitrogen metabolism and carbohydrate metabolism among different species. Also we have recognized how limited is our present knowledge on such a field of study as, for example, on the harvest index which is quite important in relation to economic yield, both as a characteristic of a genotype and as a comprehensive expression for the response of the plant to an environment. The speaker feels that in the future our physiological knowledge should be greatly extended into such field.

\section{LITERATURE CITED}

Adegbola, A. A., and C. M. McKell. 1966. Effect of nitrogen fertilization on the carbohydrate content of coastal bermudagrass (Cynodon dactylon). Agron. J. 58:60-64.

Auda, H., R. E. Blaser, and R. H. Hageman. 1966. Tillering and carbohydrate contents of orchardgrass influenced by environmental factors. Crop Sci. $6: 139-143$.

Baba, I. 1961. Mechanism of response to heavy manuring in rice varieties. IRC News Letter 10:9-16.

Baba, I., and K. Tajima. 1962. Physiological studies on the root of crop plant. III. Proc. Crop Sci. Soc. Japan 31:11-14.

Beevers, L., L. E. Schrader, F. Flesher, and R. H. Hageman. 1965. The role of light and nitrate in the induction of nitrate reductase in radish cotyledons and maize seedlings. Plant Physiol. 40:691-698.

Biddulph, O., and R. Cory. 1965. Translocation of $\mathrm{C}^{14}$-metabolites in the phloem of bean plant. Plant Physiol. 40:119-129.

Bonner, J. 1952. Plant biochemistry. Academic Press, New York.

Bourdu, R., Marie-Louse Champigny, M. Lefort, R. Remy, and A. Moyse. 1965. Structure and activities of the photosynthetic apparatus of Bryophyllum daigremontianum leaves in terms of their growth, nitrogen deficiency and nutrition. I. Physiol. Vegetale 3:305-327.

Bourdu, R., Marie-Louse Champigny, M. Lefort, M. Maslow, and A. Moyse. 1966. Tbid. II. Physiol. Vegetale 3:355-392.

Chernavskaya, N. M., and A. A. Nichiporovich. 1966. Hormonious combination of illumination and nitrogen nutrition. In A. A. Nichiporovich (ed.) Photosynthesis of productive systems. Academy of Sci. USSR (English translation, by Kaner and Monteith, 1967).

Chibnall, A. C. 1954. Protein metabolism in rooted runner-bean leaves. New Phytol. 53:31-37.

Colby, W. G., Mack Drake, D. L. Field, and G. Kreowski. 1965. Seasonal pattern of fructosan in orchardgrass stubble as influenced by nitrogen and harvest management. Agron. J. 57:169-173.

Fujiwara, A. 1965. The specific roles of nitrogen, phosphorus, and potassium in the metabolism of the rice plant, 93-105. In The mineral nutrition of the rice plant, IRRI, Johns Hopkins Press, Baltimore.

Fujiwara, A., K. Ohira, K. Otsuki, and S. Narita. 1951. Studies on the nitrogen nutrition of crops. I. J. Sci. Soil and Manure, Japan 22:91-96.

Griffith, W. K., M. R. Teel, and H. E. Parker. 1964. Influence of nitrogen and potassium on the yield and chemical composition of orchardgrass. Agron. J. $56: 473-475$. 
Hageman, R. H., and D. Flesher. 1960. Nitrate reductase activity in corn seedlings as affected by light and nitrate content of the nutrient media. Plant physiol. 35:635-641.

Hageman, R. H., D. Flesher, and A. Gitter. 1961. Diurnal variation and other light effects influencing the activity of nitrate reductase and nitrogen metabolism in corn. Crop Sci. 1:201-204.

Harper, J. E., and G. M. Paulsen. 1967. Changes in reduction and assimilation of nitrogen during the growth cycle of winter wheat. Crop Sci. 7:205-209.

Hoshino, T., S. Matsushima, and A. Matsuzaki. 1969. Analysis of yield-determining process and its application to yield prediction and culture improvement of lowland rice. 94. Proc. Crop. Sci. Soc. Japan 38: (in press).

Ishizuka, Y., and A. Tanaka. 1956a. Studies on ecological characteristics of rice plant grown in different localities, especially from standpoint of nutriophysiological characters of plant. Part I. J. Sci. Soil and Manure, Japan $27: 1-6$.

Ishizuka, Y., and A. Tanaka. 1956b. Nutrio-physiological characteristics of growth process of rice plant in different localities. Ibid. 27:95-99.

Ito, S., and S. Sakamoto. 1942. Studies on rice blast. Report for 1941. Min. of Agr. and Forestry, Tokyo.

Izawa, G., Y. Ohi, and S. Okamoto. 1966. Utilization of nitrate nitrogen in higher plant. Part 2. J. Sci. Soil and Manure, Japan 37:558-562.

Knipmeyer, J. W., R. H. Hageman, E. B. Earley, and R. D. Seif. 1962. Effect of light intensity on certain metabolites of the corn plant (Zea mays L.). Crop Sci. 2:1-5.

Kumura, A. 1956a. Studies on the effect of internal nitrogen concentration of rice plant on the constitutional factor of yield. Proc. Crop Sci. Soc. Japan $24: 177-180$.

Kumura, A. 1956b. Studies on the production and behavior of carbohydrates in rice plant. III. ibid. 24:324-330.

Matsushima, S. 1957. Analysis of developmental factors determining yield and yield-prediction in lowland rice. Bull. Nat. Inst. Agr. Sci. Japan, Ser. A, 5:1-271.

Matsuura, K. T. Iwata, and T. Hasegawa. 1969. Studies on the effect of deeplayer application of fertilizers in rice plant. I. Proc. Crop Sci. Soc. Japan 38: (in press).

McKee, H. S. 1962. Nitrogen metabolism in plants. Clarendon Press, Oxford, London. $728 \mathrm{p}$.

Menke, W. 1966. The structure of the chloroplasts, p. 3-18. In T. W. Goodwin (ed.) Biochemistry of chloroplasts. Vol. I. Academic Press, London and New York.

Mitsui, S., and T. Ishii. 1938. Effect of differences in three major elements supply quantity on the efficiency of carbon assimilation of the young rice plant. J. Sci. Soil and Manure, Japan 12:287-289.

Mitsui, S., and T. Ishii. 1939. Effect of nitrogen topdressing. J. Sci. Soil and Manure, Japan 13:309-313.

Monsi, M., und T. Saeki. 1953. Über den Lichtfaktor in den Pflanzengesellschaften und seine Bedeutung für die Stoffproduktion. Jap. J. Bot. 14:22-52.

Mothes, K., und L. Engelbrecht. 1956. Über den Stickstoffumsatz in Blattstecklingen. Flora 143:428-472.

Murata, Y. 1961. Studies on the photosynthesis of rice plants and its culture significance. Bull. Nat. Inst. Agr. Sci. Japan, Ser. D,9:1-169.

Murata, Y. 1965. Photosynthesis, respiration and nitrogen response, p. 385400. In The mineral nutrition of the rice plant. IRRI, Johns Hopkins Press, Baltimore.

Murata, Y., J. Iyama, M. Himeda, S. Izumi, A. Kawabe, and Y. Kanzaki. 1966. Studies on the deep-plowing, dense-planting cultivation of rice plants from the point of view of photosynthesis and production of dry matter. Bull. Nat. Inst. Agr. Sci. Japan, Ser. D,15:1-53. 
Murata, Y., J. Iyama, and T. Honma. 1965. Studies on the photosynthesis of rice plants. XIII. Proc. Crop Sci. Soc. Japan 34:148-153.

Murayama, N. 1967. A discussion on the leveling-off trend of rice yield in Japan and measures to level it up. J. Jap. Soc. Plant Physiologists 6:25-32.

Murayama, N., M. Yoshino, M. Oshima, S. Tsukahara, and Y. Kawarazaki. 1955. The process of carbohydrate accumulation associated with growth of rice plants. Bull. Nat. Inst. Agr. Sci., Japan, Ser. B,4:123-164.

Navasero, S. A., and A. Tanaka. 1966. Low-light induced death of lower leaves of rice and its effect on grain yield. Plant and Soil 14:17-31.

Ogata, S., and Y. Ishizuka. 1967a. Variation of nutrio-physiological characters of crops in the process of their crossing. Part 1. J. Sci. Soil and Manure, Japan 38:79-84.

Ogata, S., and Y. Ishizuka. 1967b. Variation of nutrio-physiological characters of crops in the process of their crossing. Part 2. J. Sci. Soil and Manure, Japan 38:131-134.

Ogata, S., and Y. Ishizuka. 1967c. Variation of nutrio-physiological characters of crops in the process of their crossing. Part 3. J. Sci. Soil and Manure, Japan 38:466-468.

Ojima, M., J. Fukui, and I. Watanabe. 1965. Studies on the seed production of soybean. II. Proc. Crop Sci. Soc. Japan 33:437-442.

Okajima, H. 1960. Studies on the physiological function of the roots system in the rice plant, viewed from the nitrogen nutrition. Bull. Inst. Agr. Res. Tohoku Univ. $12(1): 1-146$.

Oritani, T. 1963. The role of root in nitrogen metabolism of crop plants. Proc. Crop Sci. Soc. Japan 31:277-283.

Oritani, T., and R. Yoshida. 1967. Studies on nitrogen metabolism in crop plant. II. Proc. Crop Sci. Soc. Japan 36:509-513.

Oshima, M. 1962. Studies on the nitrogen nutrition of plant. J. Sci. Soil and Manure, Japan 33:243-246.

Osada, A. 1964. Studies on the photosynthesis of indica rice. Proc. Crop Sci. Soc. Japan $33: 69-76$.

Osada, A. 1966. Relationship between photosynthetic activity and dry matter production in rice varieties, especially as influenced by nitrogen supply. Bull. Nat. Inst. Agr. Sci. Japan, Ser. D,14:117-188.

Osada, A., and Y. Murata. 1962. Studies on the relationship between photosynthesis and varietal adaptability for heavy manuring in rice plants. I. Proc. Crop Sci. Soc. Japan 30:220-223.

Osada, A., and Y. Murata. 1965. ibid. III. Effects of photosynthetic characteristics on dry matter production and ripening of rice varieties. Proc. Crop Sci. Soc. Japan 33:460-466.

Ota, Y., and N. Yamada. 1965. Studies on sterility of indica rice. Part 2. Jap. J. Trop. Agr. 9:76-79.

Pate, J.S. 1966. Photosynthesizing leaves and nodulated roots as donors of carbon to protein of the shoot of the field pea (Pisum arvense L.) Ann. Bot. (London) 30:93-109.

Sato, K. 1956. Studies on the starch content in the tissues of rice plant. II. Proc. Crop Sci. Soc. Japan 24:154-155.

Shimizu, T. 1967. Processes of yield-formation in rice plants from the point of dry matter production. Matter Production in Crops 4:12-26.

Soga, Y., and M. Nozaki. 1957. Studies on the relation between sea sonal changes of carbohydrates accumulation and the ripening at the stage of generative growth in rice plant. Proc. Crop Sci. Soc. Japan 26:105-108.

Stansel, J. W., C. N. Bollich, J. R. Thysell, and V. L. Hall. 1965. The influence of light intensity and nitrogen fertility on rice yield and components of yield. Rice J. 68:34-35. 
Takahashi, J., M. Yanagisawa, M. Kono, F. Yazawa, and T. Yoshida. 1955. Influence of the amount of application of nitrogenous fertilizer upon the composition of paddy rice plants. Bull. Nat. Inst. Agr. Sci. Japan, Ser. B,4:85-122.

Takahashi, Y., I. Iwata, and I. Baba. 1959. Studies on the varietal adaptability for heavy manuring in rice. I. Proc. Crop Sci. Soc. Japan 28:22-24.

Takeda, T. 1961. Studies on the photosynthesis and production of dry matter in the community of rice plants. Jap. J. Bot. 17:403-407.

Tanaka, A. 1958. Studies on the physiological characteristics and significance of rice leaves in relation to their position on the stem. XI. J. Sci. Soil and Manure, Japan 29:327-333.

Tanaka, A., K. Kawano, and J. Yamaguchi. 1966. Photosynthesis, respiration, and plant type of the tropical rice plant. Int. Rice Res. Inst. Tech. Bull. 7:146.

Tanaka, A., S. A. Navasero, C. V. Garcia, G. T. Parao, and E. Ramirez. 1964. Growth habit of the rice plant in the tropics and its effect on nitrogen response. Int. Rice Res. Inst. Bull. 3:1-80.

Thomas, M. D., and G. R. Hill. 1949. Photosynthesis under field condition, p. 19-52. In J. Franck and W. E. Loomis (ed.) Photosynthesis in plants. Iowa State Coll. Press, Ames, Iowa.

Thorne, G. N. 1965. Physiological aspects of grain yield, p. 89-105. In F. L. Milthorpe and J.D. Ivin (ed.) The growth of cereals and grasses. $\bar{M} u t t e r-$ worths, London.

Togari, Y., and Y. Kashiwakura. 1958. Studies on the sterility in rice plant induced by superabundant nitrogen supply and insufficient light intensity. Proc. Crop Sci. Soc. Japan 27:3-5.

Togari, Y., Y. Okamoto, and A. Kumura. 1954. Studies on the production and behavior of carbohydrates in rice plant. I. Proc. Crop Sci. Soc. Japan 22:9597.

Togari, Y., and K. Sato. 1954. Studies on the production and behavior of carbohydrates in rice plant. II. Proc. Crop Sci. Soc. Japan 22:98-99.

Togari, Y., and T. Oritani. 1960. The role of root in nitrogen metabolism of crop plants. Proc. Crop Sci. Soc. Japan 29:71-74.

Tokitsu, T., Y. Muraoka, and M. Oka. 1957. On the functional differentiation of taproots and adventitious roots in tobacco. Proc. Crop Sci. Soc. Japan 26:5354.

Tsuno, Y. 1968. Analysis of dry matter production in high yield rice. Proc. JIBP-PP-Photosynthesis Symposium on comparative studies on the primary productivity in terrestrial plant community.

Tsuno, Y., and K. Fujise. 1965. Studies on the dry matter production of sweet potato. Bull. Nat. Inst. Agr. Sci. Japan, Ser. D,13:1-131.

Wada, G. 1969. Influence of nitrogen fertilizer on the yield and yield components in rice plants. Bull. Nat. Inst. Agr. Sci. Japan, Ser. A,16:27-167.

Wada, G., and S. Matsushima. 1962. Analysis of yield-determining process and its application to yield prediction and culture improvement of lowland rice. LXIII. Proc. Crop Sci. Soc. Japan 31:23-26.

Wada, S., and T. Kudo. 1965. Varietal difference of yield of rice plants in response to the direct supply of fertilizers to the rhizosphere of the growing plants. I. Proc. Crop Sci. Soc. Japan 34:425-430.

Yamada, N. 1963. Ecology of rice plants, p. 1-122. In Y. Togari (ed.) Crop plants. Yokendo, Tokyo.

Yamada, N., Y. Ota, and K. Kushibuchi. 1957. Studies on ripening of rice. I. Proc. Crop Sci. Soc. Japan 26:111-115.

Yanagisawa, M., and J. Takahashi. 1964. Studies on the factors related to the productivity of paddy soils in Japan with special reference to the nutrition of the rice plants. Bull. Nat. Inst. Agr. Sci. Japan, Ser. B,14:41-171. 


\section{$11 \ldots$ DIscussion}

RICHARD H. HAGEMAN

University of Illinois

Urbana, Illinois

May I congratulate you, Dr. Murata, for a very thorough and well documented presentation on the physiological responses of rice to nitrogen.

I would like to recapitulate several points from your manuscript that illustrate the importance of nitrogen on morphology, physiology, and yield components of rice:

It was shown that there was a linear relationship of nitrogen content or supply with: (i) leaf area expansion rate, (ii) total leaf area development, (iii) tiller number, (iv) number of spikelets initiated/hill, (v) number of spikelets/hill, (vi) number of spikelets $/ \mathrm{m}^{2}$, and (vii) photosynthetic activity. In addition, it was stated that the nitrogen supply must be adequate to maintain the photosynthetic apparatus during the grain-filling period. It would appear that nitrogen exerts a direct and positive effect on several of the critical yield components.

Nitrogen was shown to have certain adverse effects, as excessive amounts were associated with spikelet sterility and pollen viability. These adverse effects were enhanced by low light intensities. It was also shown that nitrogen can promote vegetative growth which results in competitive plant shading that adversely affects yields. Varietal types with minimal canopy would tend to negate this aspect. In summary, it appears that high levels of ammonical salts supplied without regard to the carbohydrate status of the plant could adversely affect yield.

Because ammonium ions are the principal form of nitrogen available to paddy rice and as such are toxic to many metabolic systems, rice must maintain an adequate supply of carbohydrates (presumably keto acids) to insure prompt conversion to amino acids. It is possible that spikelet degeneration could be due to excess free ammonia in the spikelets rather than the lack of carbohydrates in the whole plant as suggested (a negative correlation between carbohydrate content and spikelet degeneration, Fig. 11-8, Murata, this book). Since neither carbohydrate nor nitrogen content of the degenerating spikelet per se was determined, it can be postulated that neither was the causal factor and that metabolite deficiency or hormonal imbalance are responsible. This suggestion is prompted by the work of E. Insleberg (Ph.D. thesis, University of Illinois, Urbana, 1956) who found that although there was no difference in levels of various sugars, nitrate accumulated in the 
nondeveloping ear of a three-eared corn hybrid (Zea mays L.). The other two ears developed normally. The accumulation of nitrate in the presence of adequate sugars indicates that metabolism was arrested.

In contrast, nitrate is the principal form of nitrogen available to the major cereal crops grown in the USA. Nitrates can be and are accumulated in the vegetation without known detriment to the plant. Recent work in our laboratory (Lowell Klepper, Ph.D. thesis, University of Illinois , 1969) has suggested that carbohydrates, specifically 3-phosphoglyceraldehyde is the energy source (NADH produced by its oxidation) for the NADH-dependent nitrate reductase. The carbohydrate product this oxidation, 1-3-diphosphoglycerate can be further transformed by the glycolytic enzymes to provide pyruvate to the Krebs cycle, thus insuring the input of a carbohydrate skeleton for amino acid formation for each molecule of nitrate reduced. This is partially illustrated in the following diagram.


The glycolytic enzymes in the cytoplasm are capable of metabolizing any of the sugar phosphates, that enter from the chloroplast, to pyruvate and at the same time generating the NADH required for reduction of nitrate to nitrite. It is suggested that this system provides a "safety factor" that explains why nitrates are "safer" fertilizers than ammoniacal salts.

In green tissue nitrite reduction is considered to occur in the chloroplast. This is based on the observations that nitrite reductase is localized with or within the chloroplast and that ferredoxin, an intermediate of the electron transport pathway of the chloroplast, is considered the electron donor for nitrite reductase. Reduced ferredoxin can also generate NADPH (via NADP reductase), which is used to reduce fixed $-\mathrm{CO}_{2}$. It appears that if reduction of nitrite and reduction of 
fixed- $\mathrm{CO}_{2}$ are in competition for light energy as suggested by A. Moyse (Plant Physiol., Russian, 6, 287, 1959) that ferredoxin is the point where competition occurs. In this vein it is interesting to speculate as to the proportion of light energy used directly for reduction of nitrite. Assuming that at certain stages in the development of the plant that the $\mathrm{C} / \mathrm{N}$ ratio of the plant is 4 and that respiration utilizes $50 \%$ of the photosynthetic product, the reduction of nitrite to ammonia would utilize $15 \%$ of the incident light. In mature plants the $\mathrm{C} / \mathrm{N}$ ratios ranging from 15:1 to $20: 1$ have been reported.

Beyond these differences it is visualized that the influence of nitrogen on morphology, physiology and yield components of the other cereal crops are very similar to those recorded by Dr. Murata for rice.

\title{
11... DISCUSSION
}

\author{
AKIRA TANAKA
}

Hokkaido University

Sapporo, Japan

The economic yield of small grains at a high grain yield level is the function of the dry matter production after flowering. The total dry matter production does not necessarily correlate with the economic yield. How to improve the dry matter production after flowering is the key for a high economic yield. Thus, discussions should be concentrated on the status of the plants at and after flowering.

An increased supply of nitrogen in the soil to a crop causes an increased uptake of nitrogen by the crop, depending upon the capacity to absorb nitrogen. Increased nitrogen uptake may result in

1) expansion of leaf area,

2) increase in nitrogen content of the leaves, and

3) increased capacity of ears as the sink to accumulate photosynthetic products of the leaves (the yield-container).

At low nitrogen levels, frequently (3) is the most dominant factor in increasing yield and analysis of the yield components has an important meaning. However, under such conditions a high yield is impossible.

With an ample supply of nitrogen it is not a difficult task to increase the size of the yield-container. For this reason, the importance of studies on the size of the yield-container may diminish if we aim at a high grain yield with heavy nitrogen application.

At high nitrogen levels where maximum yield may be obtained (1) 
may have a dominant role. Frequently excess leaf area caused by a heavy nitrogen application results in a decreased grain yield due to mutual shading of the leaves. This can be overcome by employing varieties with desirable plant types combined with improved cultural methods. Excessive nitrogen content of leaves seldom adversely affects active photosynthesis. However, generally (1) and (2) take place simultaneously, thereby complicating the situation.

The degree of response to increased nitrogen uptake in the direction of (1) or (2) depends upon climatic conditions, the timing of nitrogen application, and also on varietal characters. If one can increase nitrogen content of the leaves while keeping an optimum leaf area, a high grain yield will be obtained. At high nitrogen levels, the leaf area frequently exceeds the optimum. The increased nitrogen content of the organs also results in accelerated photosynthetic potentiality and the respiratory rate. Mutual shading of the leaves increases as does respiration of the organs which are not directly associated with grain production. These upset the balance between photosynthesis and respiration. This situation is generally discussed in terms of nitrogen and carbohydrate balance. To obtain maximum grain yield nitrogen application should be made to balance (1) and (2). How to apply nitrogen to have adequate leaf area with high nitrogen content is important in obtaining a high grain yield.

Dr. Murata discussed the point that the dry matter production is the balance between photosynthesis and respiration, and accelerated respiration has a negative effect in increasing the grain yield. However, it should be noted that there is no production of substances if there is no respiration from which energy needed for the production of substances is generated. Thus, critical studies on the efficiency of respiration in dry matter production are indispensable to evaluate the significance of increased uptake of nitrogen in producing higher grain yield. As a parameter to express the efficiency of respiration the growth efficiency, which is the efficiency of photosynthetic products in producing dry matter, seems to be a useful tool to elucidate the relationships among photosynthesis, respiration, and dry matter production, and, therefore, grain production. Growth efficiency may be associated with the morphology of plants as well as with the chemical nature of respiration which are governed by environmental conditions and by genetic factors.

Considering these points, I believe that cooperation of crop physiologists with plant breeders is indispensable for maximizing crop yield. 